http://jmscr.igmpublication.org/home/ ISSN (e)-2347-176x ISSN (p) 2455-0450 crossref DOI: https://dx.doi.org/10.18535/jmscr/v7i12.05

\author{
Journal Of Medical Science And Clinical Research \\ IGM Publication \\ An official Publication of IGM Publication
}

\title{
Cardiomyopathy in the Emergency Room
}

\author{
Authors \\ Vishal C. Bhatt ${ }^{1}$, Santoshkumar G. Thakur ${ }^{2}$
}

\begin{abstract}
Cardiomyopathy is one of the common etiologies for heart failure and causes can be ischemic, non ischemic, alcoholic, viral cardiomyopathy etc. Early recognition of the condition helps in reversing the etiology and further functional deterioration of heart. Bedside screening of 2D ECHO has helped in early recognition of the condition along with troponins which helps in ruling out ischemic cause of carsiomyopathy. Here we are presenting a case series of 4 patients who had different presentations in emergency room $(E R)$ and a diagnosis of cardiomyopathy were made with the help of either troponins, $2 D$ ECHO or angiography.
\end{abstract}

\section{Introduction}

Dilated Cardiomyopathy (DCM) which is interchangeably termed as non-ischmeic cardiomyopathy is the common form of cardiomyopathy accounting $25 \%$ of cases and is one of the important causes of heart failure. Autoimmune diseases, metabolic and toxic causes, history of viral myocarditis are few of the important causes triggering $\mathrm{DCM}^{[1]}$. Here we are presenting four cases which came with different presentations in emergency room (ER) for first time and were diagnosed as non-ischemic cardiomyopathy on further evaluation.

\section{Case 1}

A female of 42 years presented to the emergency room (ER) with history of palpitations since 1 day. No history of chest pain, breathlessness, syncope was present. Patient had no history of diabetes mellitus (DM), hypertension (HTN), chronic obstructive pulmonary disease (COPD) or tuberculosis (TB). Patients last menstrual period (LMP) was 10 days prior to the symptom onset and obstetric history was para 2 living 2 (P2L2). No family history of ischemic heart diseases or no past history of similar complaints or no addiction history like alcohol, tobacco, misri was given by patient. On examination, JVP dilated, apex beat was palpable in mid-axillary line. No murmurs were present. On presentation she had tachycardia of 170/min (regular), blood pressure of 120/90 $\mathrm{mm} \mathrm{hg}$ and respiratory rate of $28 / \mathrm{min}$. On examination, apex beat was palpable in midaxillary line. No murmurs were present. ECG was suggestive of supraventricular tachycardia (SVT). Chest X-ray was suggestive of cardiomegaly. Hemoglobin $(\mathrm{Hb})$ was $10.8 \mathrm{~g} / \mathrm{dl}$, sodium $\left(\mathrm{Na}^{+}\right)$ $136 \mathrm{mmol} / \mathrm{l}$, potassium $\left(\mathrm{K}^{+}\right) 4.0 \mathrm{mEq} / \mathrm{L}$, calcium $\left(\mathrm{Ca}^{++}\right) 8.5 \mathrm{~g} / \mathrm{dl}$. Blood values of T3,T4,TSH were $1.2 \mathrm{ng} / \mathrm{ml}, 6.7 \mathrm{mcg} / \mathrm{dl}$ and $3.12 \mathrm{mIU} / \mathrm{ml}$ respectively. High sensitivity cardiac troponin $\mathrm{T}$ (hs-cTnt) values were $18 \mathrm{ng} / \mathrm{l}, 18 \mathrm{ng} / \mathrm{l}$ and $16 \mathrm{ng} / \mathrm{l}$ at 0,3 and 6 hours respectively suggesting no increasing trend. Screening 2D ECHO was done which showed left ventricular ejection fraction (LVEF) of $15-20 \%$ with DCM. No regional wall motion 
abnormality (RWMA) or valvular abnormality was found. Immediate Pharmacological cardioversion with three doses of $6 \mathrm{mg}, 6 \mathrm{mg}$ and $12 \mathrm{mg}$ of IV adenosine was given but as SVT was not resolved, a dose of $150 \mathrm{mg}$ of IV amiodarone was given and SVT was terminated. Coronary angiography was planned after cardiology consult and revealed normal coronaries.

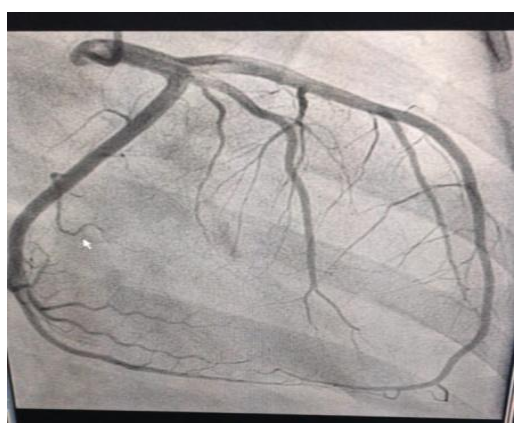

Fig. 1 Normal coronaries in CAG

A final diagnosis of non-ischemic DCM with severe heart failure was made.

\section{Case 2}

A female of 55 years presented to ER with history of progressive pedal edema since 20 days, abdominal distension since 8-10 days and progressive breathlessness since 5 days. No history of DM, HTN, COPD, TB, thyroid disorder. Patient addicted to misri since many years. Obstetric history revealed P6L6. Post menopausal since 7 years. On examination she had pulse of 96/min, BP of 140/90mmhg, RR of $28 / \mathrm{min}$ and $\mathrm{SpO} 2$ of $96 \%$ at 6 litres of oxygen. Jugular venous pressure (JVP) was raised with bilateral pedal edema present. Apex beat was palpable in mid-axillary line and basal crepitations were heard on auscultation. ECG was normal. $\mathrm{Hb}$ of patient was $11.6 \mathrm{~g} / \mathrm{dl}, \mathrm{Na}^{+}$of $137 \mathrm{mmol} / \mathrm{l}, \mathrm{K}^{+}$of $4.2 \mathrm{mEq} / \mathrm{l}$ and $\mathrm{Ca}^{++}$of $8.9 \mathrm{mg} / \mathrm{dl}$. Troponin level was $4 \mathrm{ng} / \mathrm{l}$. total bilirubin was $0.8 \mathrm{mg} / \mathrm{dl}$, SGOT of $30 \mathrm{U} / \mathrm{L}$, SGPT of $38 \mathrm{U} / \mathrm{L}$, ALP 70 IU/L, albumin of $4.2 \mathrm{~g} / \mathrm{dl}$. ProBNP levels were $8000 \mathrm{pg} / \mathrm{ml}$. Ultrasound revealed moderate ascites with hepatomegaly. Chest X-ray revealed pulmonary edema and cardiomegaly. Screening 2D ECHO was done which revealed biventricular failure with LVEF of $35-40 \%$ with DCM. No RWMA or valvular abnormalities were noted. Patient was given furosemide in ER and started on noninvasive ventilation (NIV). Based on normal troponins, a diagnosis of non ischemic DCM with heart failure was made in ER.

\section{Case 3}

A male patient of 60 years presented to ER with history of progressive breathlessness and bilateral pedal edema since 15-20 days. No history of chest pain, palpitations or syncope was present. Past history of breathlessness given 3 months back for which patient was advised tablet Deriphyllin 150 mg. No history of DM, HTN, COPD, TB or thyroid disorder was present. Patient was reformed alcoholic since 30 years. On examination pulse was 100/min, BP- 96/64 mmhg, RR- 32/min, SpO2- 95\% at room air. JVP was significantly elevated. Apex beat palpated more towards left and downward position. S1S2 heard. No murmurs on auscultation. Air entry reduced bilaterally, bilateral crepts present.ECG revealed left bundle branch block (LBBB). Chest $\mathrm{X}$-ray showed pulmonary edema. $\mathrm{Hb}$ was 13.7 $\mathrm{g} / \mathrm{dl}, \mathrm{Na}^{+} 139 \mathrm{mmol} / \mathrm{l}, \mathrm{K}^{+} 3.9 \mathrm{mEq} / \mathrm{L}, \mathrm{Ca} 9.1$ $\mathrm{mg} / \mathrm{dl}$. T3,T4,TSH levels were $1.00 \mathrm{ng} / \mathrm{ml}$, $7.2 \mathrm{mcg} / \mathrm{dl}$ and $4.25 \mathrm{mIU} / \mathrm{ml}$ respectively which were normal. ProBNP was 35000 pg/ml. Troponin was $6 \mathrm{ng} / \mathrm{ml}$. 2D ECHO screening revealed LVEF of $20-25 \%$ with DCM. No RWMA or valvular abnormalities were detected. Patient was given $60 \mathrm{mg}$ furosemide in ER and NIV was started. Cardiology consultation done and Coronary angiography was done which revealed normal coronaries.

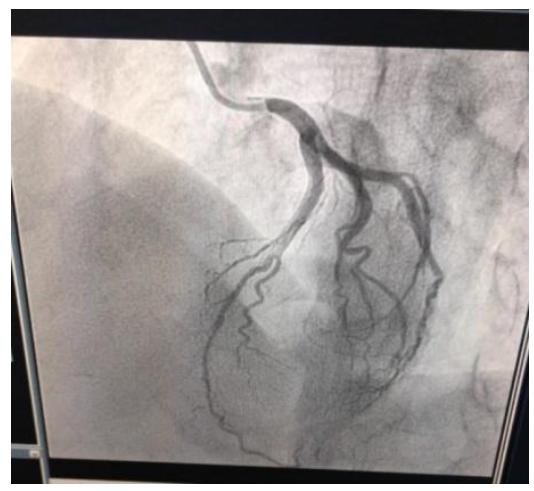

Fig. 2 Normal coronaries in CAG

A diagnosis of non-ischemic DCM with heart failure was confirmed. 


\section{Case 4}

A male of 75 years, presented with history of sudden onset progressive breathlessness since 2 days. No history of chest pain, palpitations, syncope, pedal edema, oliguria was present. Patient was a known case of DM since 20 years and was on tablet metformin $500 \mathrm{mg}$ and tablet glimepiride $2 \mathrm{mg}$. No history of HTN, COPD, TB or thyroid disorder was present. On presentation he had heart rate of $116 / \mathrm{min}$, blood pressure of $170 / 110 \mathrm{mmhg}$, respiratory rate of $30 / \mathrm{min}$ and $\mathrm{SpO} 2$ of $98 \%$ at 8 litres of oxygen. JVP was elevated. Apex beat was palpable in mid-axillary line and bilateral crepitations heard on auscultation. ECG revealed left ventricular hypertrophy. Chest X-Ray showed pulmonary edema. $\mathrm{Hb}$ was $12.6 \mathrm{~g} / \mathrm{dl}, \mathrm{Na}^{+} 136 \mathrm{mmol} / \mathrm{l}, \mathrm{K}^{+} 4.8$ $\mathrm{mEq} / \mathrm{L}, \mathrm{Ca} 8.7 \mathrm{mg} / \mathrm{dl}$. T3,T4,TSH levels were $1.25 \mathrm{ng} / \mathrm{ml}, \quad 8.5 \mathrm{mcg} / \mathrm{dl}$ and $3.25 \mathrm{mIU} / \mathrm{ml}$ respectively which were normal. ProBNP was $35000 \mathrm{pg} / \mathrm{ml}$. Troponin was $20 \mathrm{ng} / \mathrm{ml}, 18 \mathrm{ng} / \mathrm{ml}$, $12 \mathrm{ng} / \mathrm{ml}$ after $0,3,6$ hours respectively. ProBNP was $9000 \mathrm{pg} / \mathrm{ml}$. Ultrasound of abdomen was normal. Screening 2D- echo done which showed LVEF of $30 \%$ with DCM. No RWMA or valvular abnormality noted. Infusion of Furosemide at $10 \mathrm{mg} / \mathrm{hr}$ and nitroglycerin at $5 \mathrm{mcg} / \mathrm{min}$ were started in ER and NIV support started. A diagnosis of non-ischemic cardiomyopathy with heart failure was made in ER.

\section{Table 1 Summary}

\begin{tabular}{|l|c|c|c|c|}
\hline & Patient 1 & Patient 2 & Patient 3 & Patient 4 \\
\hline Age-Sex & $42 / \mathrm{F}$ & $55 / \mathrm{F}$ & $65 / \mathrm{M}$ & $75 / \mathrm{M}$ \\
\hline $\begin{array}{l}\text { Present- } \\
\text { ation }\end{array}$ & Palpitations & $\begin{array}{c}\text { Breathlessness } \\
\text { Abdomin-al } \\
\text { distensio-n } \\
\text { Pedal edema }\end{array}$ & Breathlessness & Preathlessness \\
\hline $\begin{array}{l}\text { Co- } \\
\text { morbidities }\end{array}$ & Absent & Absent & Absent & Diabetes \\
\hline Vitals & Unstable & Unstable & Unstable & Unstable \\
\hline ECG & SVT & Normal & LBBB & LVH \\
\hline Troponins & $\begin{array}{c}\text { Mildly } \\
\text { Elevate-d, } \\
\text { but not in } \\
\text { trend }\end{array}$ & Normal & $\begin{array}{c}\text { Mildly } \\
\text { Elevated but } \\
\text { not in trend }\end{array}$ & $\begin{array}{c}\text { Mildly } \\
\text { Elevated but } \\
\text { not in trend }\end{array}$ \\
\hline $\begin{array}{l}\text { 2D-ECHO } \\
\text { LVEF with } \\
\text { DCM }\end{array}$ & $\begin{array}{c}40 \% \text { LVEF } \\
\text { with DCM }\end{array}$ & $\begin{array}{c}\text { 20-25\% } \\
\text { LVEF with } \\
\text { DCM }\end{array}$ & $\begin{array}{c}\text { 30\% LVEF } \\
\text { with DCM }\end{array}$ \\
\hline $\begin{array}{l}\text { Diagn-osis } \\
\text { based on }\end{array}$ & CAG & $\begin{array}{c}\text { Screening } \\
\text { 2DECHO and } \\
\text { troponin }\end{array}$ & CAG & $\begin{array}{c}\text { Screening } \\
\text { 2DECHO and } \\
\text { troponin }\end{array}$ \\
\hline
\end{tabular}

\section{Discussion}

The term dilated cardiomyopathy (DCM) refers to a spectrum of heterogeneous myocardial disorders that are characterized by ventricular dilation and depressed myocardial performance in the absence of hypertension, valvular, congenital, or ischemic heart disease ${ }^{[4]}$. According to ADHERE (Acute Decompensated Heart Failure National Registry), $47 \%$ of the patients admitted to the hospital with HF had non-ischemic cardiomyopathy ${ }^{[5]}$. All patients in the case series never showed any symptom of cardiomyopathy except may be in patient 3. This should be kept in mind as some patients never show any signs or symptoms or are diagnosed late ${ }^{[6]}$. Echocardiography has crucial importance in the diagnosis of dilated cardiomyopathy $(\mathrm{DCM})^{[7]}$. In patients with suspected heart failure or LV dysfunction, echocardiography is the most important investigation in establishing the diagnosis of DCM, by defining the presence and severity of LV dilatation and dysfunction. Diagnostic criteria have relied on the identification of an ejection fraction $(\mathrm{EF}), 45 \%$, and/or a fractional shortening ,25\%, in association with a LV end-diastolic dimension $.112 \%$ predicted value corrected for age and body surface area. Echocardiography, however, not only facilitates evaluation of strict diagnostic criteria, but also provides us with a powerful tool with which to make a comprehensive assessment of cardiac anatomy, pathophysiology, and haemodynamics ${ }^{[8]}$. 2D ECHO revealed DCM in all 4 patients. All 4 patients had LVEF of less than or equal to $40 \%$. LV dysfunction has long been regarded as the main determinant of clinical symptoms, functional class, and prognosis in $\mathrm{DCM}^{[8]}$. All 4 patients were ruled out for ischemic cardiomyopathy either via troponins or $2 \mathrm{D}$ ECHO screen or coronary angiography. 2 patients underwent coronary angiography. Coronary angiography is still the first choice method for the diagnosis of coronary artery disease in patients with dilated cardiomyopathy. The diagnosis of coronary artery disease is, in its turn, essential as patients with 
associated coronary artery disease have a worse prognosis, compared to patients with idiopathic dilated cardiomyopathy, and, more importantly, coronary revascularization may significantly improve left ventricular function, clinical symptoms and prognosis, when performed in the presence of a significant amount of viable myocardium. The favorable effects on the left ventricular function are greater when a contractile reserve is shown. However, revascularization of viable myocardium may have other beneficial effects like a reduction in left ventricular remodeling and in the incidence of recurrent ischemic events and malignant arrhythmias ${ }^{[9]}$.

\section{Conclusion}

Cardiomyopathy should be considered in every patient of cardiac ischemia above age of 40 . Absence of chest pain and screening 2D ECHO in ER can help in early suspicion of DCM. After ruling out ischemia, further management can be carried out in finding and treating cause of DCM.

\section{Acknowledgement: Nil}

\section{References}

1. Yancy CW, Jessup M, Bozkurt B, Butler J, Casey DE Jr, Drazner MH, Fonarow GC, Geraci SA, Horwich T, Januzzi JL, Johnson MR, Kasper EK, Levy WC, Masoudi FA, McBride PE, McMurray JJ, Mitchell JE, Peterson PN, Riegel B, Sam F, Stevenson LW, Tang WH, Tsai EJ, Wilkoff BL. 2013 ACCF/AHA guideline for the management of heart failure: executive summary: a report of the American College of Cardiology Foundation/American Heart Association Task Force on practice guidelines. Circulation. 2013;128:1810-1852.

2. Dec GW, Fuster V. Idiopathic dilated cardiomyopathy. N Engl J Med. 1994;331:1564-1575.
3. Sugrue DD, Rodeheffer RJ, Codd MB, Ballard DJ, Fuster V, Gersh BJ. The clinical course of idiopathic dilated cardiomyopathy: a population-based study. Ann Intern Med. 1992;117:117-123.

4. Richardson P, McKenna W, Bristow M, Maisch B, Mautner B, O'Connell J, Olsen E, Thiene G, Goodwin J, Gyarfas I, Martin I, Nordet P. Report of the 1995 World Health Organization/International Society and Federation of Cardiology Task Force on the Definition and Classification of cardiomyopathies. Circulation. 1996;93:841-842

5. Fonarow GC et al ADHERE Scientific Advisory Committee. The Acute Decompensated Heart Failure National Registry (ADHERE): opportunities to improve care of patients hospitalized with acute decompensated heart failure.Rev Cardiovasc Med 2003;4 Suppl 7:S21-30

6. 6- National Heart, Lung, and Blood Institute. Diseases and Conditions Index. Types of cardiomyopathy.

7. Pinamonti B, Cacciatore G. Dilated cardiomyopathy: indication and role of non-invasive instrumental evaluation. Ital Heart J Suppl. 2002 Apr;3(4):405-11.

8. Dewi E. Thomas, Richard Wheeler, Zaheer R. Yousef, Navroz D. Masani, The role of echocardiography in guiding management in dilated cardiomyopathy, European Journal of Echocardiography, Volume 10, Issue 8, December 2009, Pages iii15-iii21.

9. Metra M, Nodari S, Trussardi E, Vizzardi E, Cas LD.Dilated cardiomyopathy: indication and role of invasive evaluation. Ital Heart J Suppl. 2002 Apr;3(4):412-8. 